\title{
Advances in the understanding of priapism
}

\author{
Matthew Hudnall, Amanda B. Reed-Maldonado, Tom F. Lue \\ Department of Urology, University of California, San Francisco, San Francisco, CA 94143-0738, USA \\ Contributions: (I) Conception and design: AB Reed-Maldonado, TF Lue; (II) Administrative support: TF Lue; (III) Provision of study materials or \\ patients: TF Lue; (IV) Collection and assembly of data: All Authors; (V) Data analysis and interpretation: All Authors; (VI) Manuscript writing: All \\ Authors; (VII) Final approval of manuscript: All Authors. \\ Correspondence to: Tom F. Lue. Department of Urology, University of California, San Francisco, 400 Parnassus Avenue, Suite A610, San Francisco, \\ CA 94143-0738, USA. Email: Tom.Lue@ucsf.edu.
}

\begin{abstract}
Priapism, a persistent penile erection lasting longer than 4 hours and unrelated to sexual activity, is one of the most common emergencies treated by urologists. Priapism can be categorized as ischemic, recurrent ischemic (stuttering), and non-ischemic. Advances in understanding the pathophysiology of various types of priapism have led to targeted management strategies. This review aims to provide an up-to-date picture of the pathophysiology and management of priapism. A search of Medline and PubMed for relevant publications using the term "priapism" was performed. In addition to the "classical" articles, emphasis was placed on publications from January 2013 to September 2016 to evaluate the most recent literature available. Though advances in both basic and clinical research continue and effective treatment options are available, methods for the prevention of priapism continue to be elusive.
\end{abstract}

Keywords: High-flow priapism; ischemic priapism; non-ischemic priapism; recurrent ischemic; stuttering priapism

Submitted Dec 22, 2016. Accepted for publication Dec 25, 2016.

doi: $10.21037 /$ tau.2017.01.18

View this article at: http://dx.doi.org/10.21037/tau.2017.01.18

\section{Introduction}

Priapism is one of the most common urologic emergencies. Priapism is defined as a prolonged and persistent penile erection that is unrelated to sexual interest or stimulation and lasts longer than 4 hours in duration (1). Three main types of priapism have been defined: ischemic (low flow), non-ischemic (high flow), and stuttering (recurrent). The following paper will briefly review the pathogenesis and management options for treating priapism.

Several clinical advances have been made that allow for rapid treatment of the acute episode of ischemic, low-flow priapism. Rapid treatment is vital to ensure the least amount of long-term disability. It is recommended that treatment be initiated with aspiration and injection of a diluted alphaadrenergic agent (1). If this is ineffective or if the duration of the episode has been prolonged, it is recommended that a $\mathrm{T}$ shunt procedure be performed. One of the most frequent complications of the surgical treatment of low-flow priapism is shunt failure (2). Exposure of blood to collagen during surgical creation of the shunt can lead to clotting and premature shunt closure (2). Perioperative anticoagulation should be initiated immediately after identifying the need for a surgical shunt procedure and continued into the postoperative period. Timely anticoagulation will minimize shunt failure and maximize treatment success (2).

For non-ischemic priapism, treatment options include observation, selective arterial embolization, and surgical intervention as the last resort (1). Current treatment options that we recommend include treatment with antiandrogens, such as bicalutamide or ketoconazole, or GnRH agonists for 3-4 months (3). This avoids the need for invasive intervention, and this treatment has minimal associated morbidity with transient side effects (3).

Finally, in patients who present with recurrent priapism, androgen ablation therapy is an effective and proven therapy. However, in young men with sickle cell disease, treatment with low dose type 5 phosphodiesterase inhibitors 


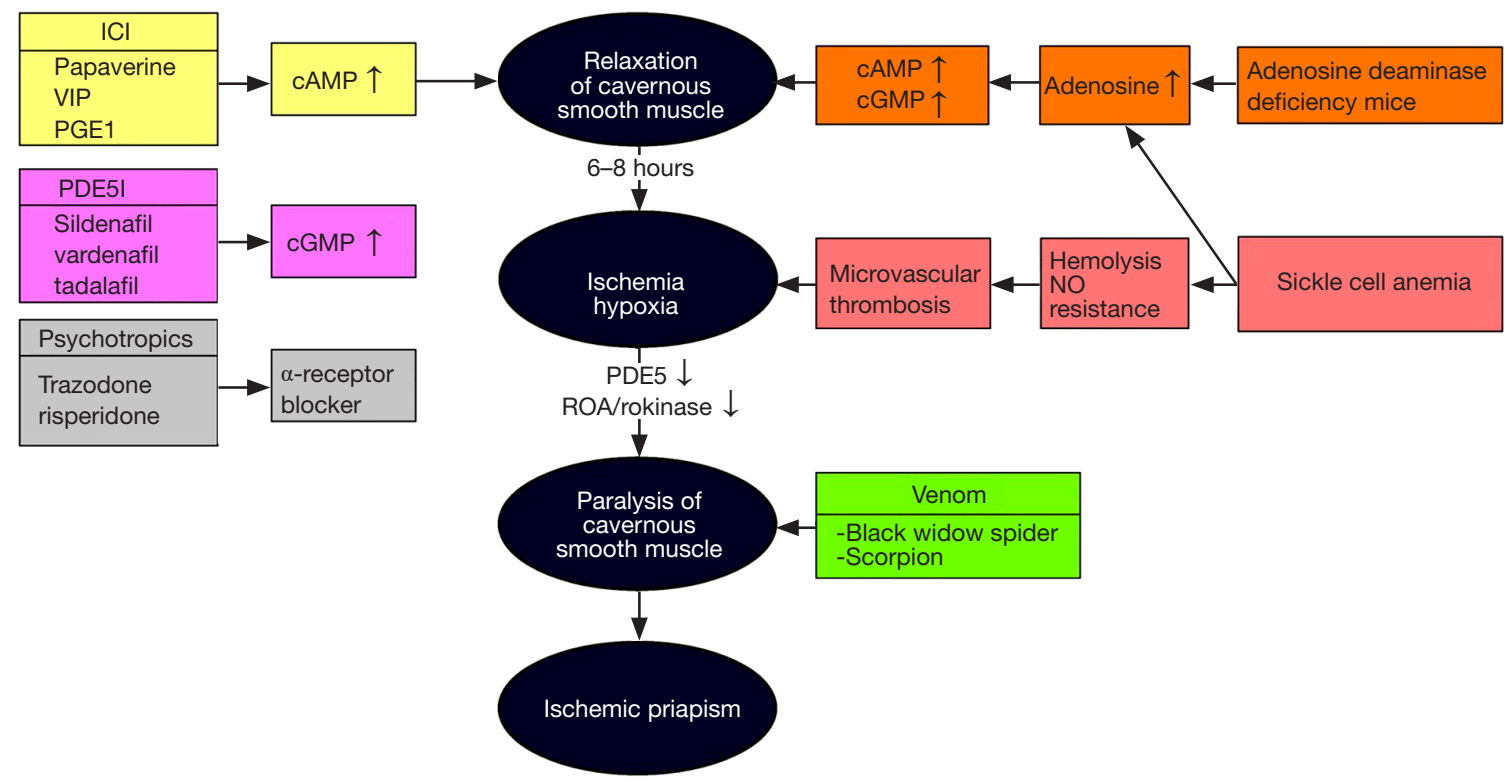

Figure 1 Ischemic priapism pathogenesis.

seems to be a better alternative (4).

\section{Epidemiology}

Ischemic priapism is the most common presentation of priapism, with an incidence of up to 5.34 per 100,000 men per year (5). Ischemic priapism is most often idiopathic, and the disorder disproportionately affects patients with sickle cell disease (5). Non-ischemic priapism, on the other hand, is usually the result of perineal trauma and occurs less frequently than ischemic priapism (4).

\section{Ischemic priapism}

\section{Pathogenesis}

Ischemic priapism is usually the result of occluded venous outflow from the corpora cavernosa, which prevents arterial inflow and leads to tissue ischemia, endothelial and smooth muscle damage, and subsequent fibrosis $(1,6)$. Etiologies of ischemic priapism include malignancy, medications such as phosphodiesterase-5 inhibitors (7), trazadone (8) and amphetamines (9), spinal cord injury (10), and hematologic conditions, such as sickle cell disease and glucose-6phosphate deficiency (Figure 1) $(11,12)$. Most often ischemic priapism is idiopathic. Sickle cell disease patients tend to present with recurrent ischemic (stuttering) priapism and are the focus of much of the research into the underlying molecular mechanisms of the disorder (13).

\section{Management}

Erectile dysfunction is a common sequela of ischemic priapism. This is particularly true among sickle cell disease patients, who are up to five times more likely to develop ED compared to non-sickle cell disease patients (14). Given the severity of this outcome, early recognition of the condition and prompt management are essential. Ischemic priapism is typically managed within the first 24 hours with corporal aspiration and intracavernous injection of an alphaadrenergic agent such as diluted phenylephrine, the preferred agent for early management (Figure 2) (15). Other vasoactive agents, such as oral terbutaline, have been deemed less effective than phenylephrine (16). Beyond 24 hours, or if conservative management fails, surgical intervention is usually required for detumescence. Typically, a distal shunt between the corpora and the glans is created using a percutaneous (Ebbehoj or Winter shunt, T-shunt) or open (Al-Ghorab) procedure $(15,17,18)$. The choice often depends on surgeon familiarity but should proceed from least to most invasive.

For patients with an ischemic priapism duration of longer than 2 days, severe intracavernous tissue edema may prevent effective blood flow from the proximal to distal penis (6). 


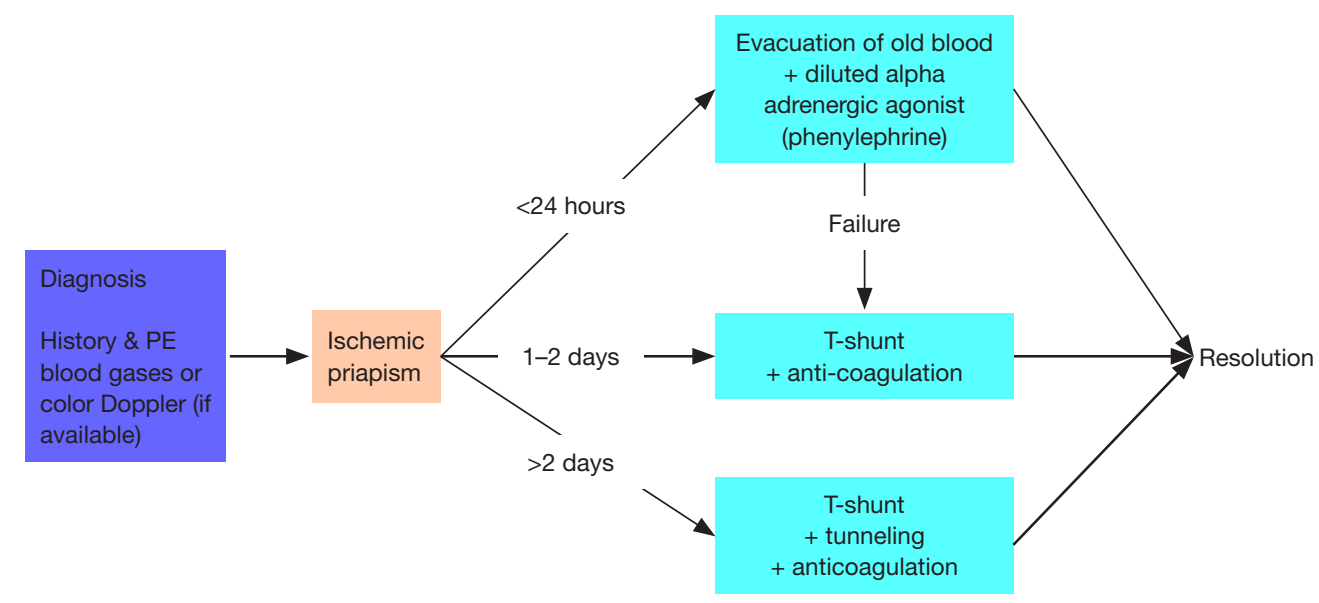

Figure 2 Ischemic priapism management.

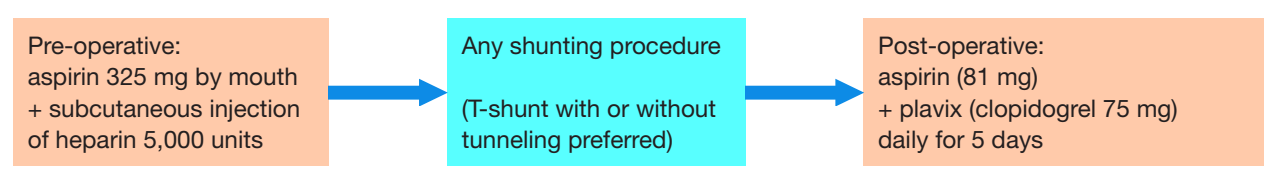

Figure 3 Perioperative anticoagulation to prevent recurrence of priapism.

In the past, proximal shunt (19) and cavernosum-venous shunt (20) have been the standard approaches. However, these technically challenging and lengthy procedures have been replaced by tunneling procedures developed by Lue $e t$ al. $(18,21)$ and Burnett et al. $(17,22)$. It is important to recognize that all the above procedures require incision through the tunica albuginea and expose collagen to coagulation factors in the penile blood and thus activate the blood-clotting cascade. Perioperative anticoagulation is therefore an important key to successful resolution of priapism (Figure 3) (2).

Early penile prosthesis implantation has also been advocated for patients with an ischemic episode lasting greater than 48 hours before intervention (23). Early implantation within 2 weeks of the ischemic priapism episode results in fewer post-operative complications, such as erosion or infection, than implantation that is delayed by 2 or more months, and patients generally have higher satisfaction and experience less penile shortening (23). Immediate implantation of a malleable penile prosthesis allows for upsizing with an inflatable prosthesis without significant difficulty at a later operation (24) and may lead to long-term cost savings and decreased utilization of hospital resources (25).

\section{Non-ischemic (bigh-flow) priapism}

\section{Pathogenesis}

Non-ischemic priapism is usually caused by perineal or penile trauma and can occur after shunt procedures for management of ischemic priapism $(7,26-28)$. Following trauma, initial vascular injury to the cavernosal artery or helicine arteries is exacerbated by nocturnal erections or erections related to sexual activity $(3,28)$. Ultimately, high-flow priapism occurs when a fistula forms between the artery and the sinusoidal spaces of the corpora cavernosa. The resultant unregulated arterial inflow causes a persistent erection that is generally painless because venous drainage is not compromised and penile tissue does not become ischemic (27).

\section{Management}

Initial management of non-ischemic priapism is typically observation and penile compression, as the condition may self-resolve and the tissue is not at risk for ischemic necrosis (Figure 4) (1). Failure of conservative therapy typically prompts treatment via selective temporary arterial embolization using autologous clot or gel foam, or permanent arterial embolization through coiling or n-butyl-2 cyanoacrylate $(1,4,12,29,30)$. Computed 


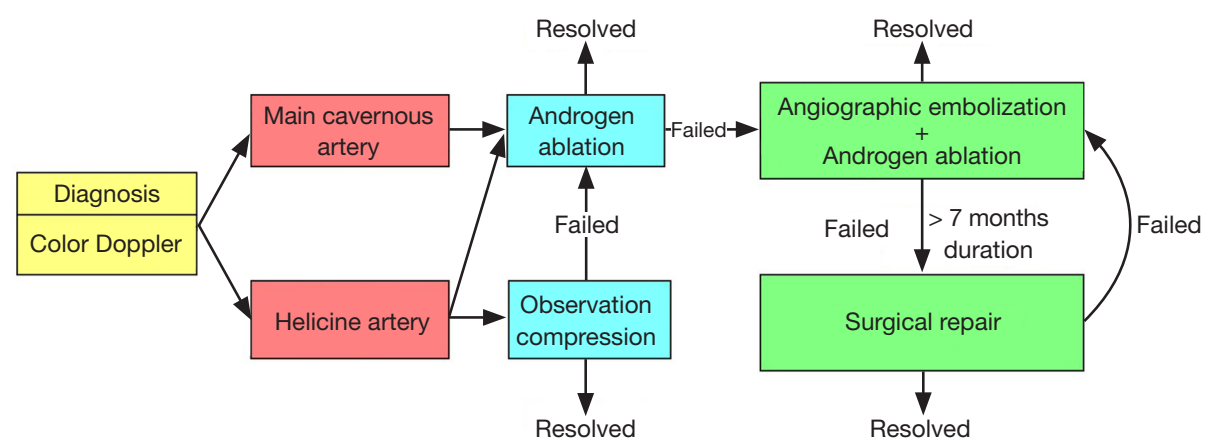

Figure 4 Non-ischemic priapism management.

tomographic angiography can be used to facilitate identification of the damaged vessel in three dimensions (31). More recently, percutaneous direct puncture embolization with n-butyl-2 cyanoacrylate has been used to successfully treat high flow priapism recurrence after failure of traditional arterial embolization (32).

Non-invasive medical therapy with androgen ablation can provide an effective alternative to the above invasive procedures $(3,28)$. In a study of seven men with high flow priapism, treatment with leuprolide, bicalutamide, and fluconazole led to resolution of symptoms in six men after a treatment period ranging from 2 to 6 months (3). Androgen blockade is thought to reduce sleep-related erections and facilitate closure of vascular injury after trauma (3). These results have prompted a treatment algorithm that proposes trial of androgen ablation prior to embolization if the highflow priapism is caused by damage to the cavernous artery (28).

\section{Stuttering (recurrent ischemic) priapism}

\section{Pathogenesis}

Stuttering priapism is defined as periodic episodes of prolonged erections that may lead to recurrent ischemic priapism (1). Episodes often occur during sleep or with sexual stimulation, and may resolve spontaneously (7). Because stuttering priapism tends to affect sickle cell disease patients more commonly than non-sickle cell disease patients (33), microvascular occlusion due to hemolysis and stasis of sickled erythrocytes is thought to be a significant contributing factor. Sickle cell patients with priapism have higher rates of hemolysis than sickle-cell men without priapism, as well as a higher red blood cell disaggregation threshold and lower red blood cell deformability, a pattern similarly found in sickle cell patients who experience leg ulcers and glomerulonephropathy (34). More recently, animal models and clinical studies have revealed a role for abnormal nitric oxide (NO) and cyclic guanosine monophosphate (cGMP) signaling and regulation in the pathogenesis of stuttering priapism (35-40).

Normal erectile physiology involves the generation of NO by neuronal nitric oxide synthase (nNOS) and endothelial nitric oxide synthase (eNOS) in response to sexual stimulation $(36,41)$. NO diffuses into cavernosal smooth muscle, causing relaxation and sinusoidal vasodilation through downstream cGMP signaling (42). cGMP is then hydrolyzed and inactivated by phosphodiesterase type 5 (43), leading to smooth muscle vasoconstriction and return of the penis to its flaccid state. The normal erectile response and detumescence is achieved through a balance of these signaling molecules, and dysregulation can result in either erectile dysfunction or priapism $(41,44,45)$.

Improper PDE5 regulation and subsequent aberrant $\mathrm{NO}$ signaling appears to be an important cause of stuttering priapism (Figure 1) (35). Production of PDE5 is cGMPdependent, and a basal decrease in the activity of cGMP leads to transcriptional downregulation of PDE5, resulting in dysfunctional termination of the erectile response (40). The low basal levels of cGMP are thought to stem from decreased bioavailability of NO, which may be due to endothelial damage and decreased eNOS activity and scavenging of NO by reactive oxygen species or free hemoglobin released through hemolysis, particularly in sickle cell disease patients (45). In a mouse model of sub-acute hemolysis where mice were transplanted with sicklephenotype bone-marrow 3-4 months prior to study, a priapism phenotype with increased erection frequency and intra-cavernosal pressure was able to be demonstrated (46). The results suggest that the hemolysis need not be chronic to lead to priapism. Subacute hemolysis was associated 
with decreased activity of nitrous oxide synthase, protein kinase G, and PDE5, and increased reactive oxygen species compared to control mice that did not receive sickle marrow transplantation (46).

Other signaling pathways involving adenosine, RhoA/ rock and opiorphin may also be involved in the pathogenesis of priapism $(47,48)$. Adenosine deaminase-deficient mice cannot convert adenosine to its inactive form, and these mice demonstrate a priapism phenotype (48). In a mouse model of sickle cell disease, CD73, a molecule responsible for converting adenosine mononucleotides to adenosine, is upregulated compared to non-sickle cell mice (49). Elevation of CD73 is also found in an in-vitro model of corporal hypoxia, and is dependent on the hypoxia-induced upregulated expression of sialorphin, a murine homologue of opiorphin (49). Corporal smooth muscle cells from a rat model of sickle cell disease demonstrate an upregulation in sialorphin in response to hypoxic conditions that leads to an increased expression of hypoxia inducible factor $1 \mathrm{~A}$ (Hif- $1 \alpha$ ) and the $\mathrm{A} 2 \mathrm{~B}$ adenosine receptor (A2Br) (50). A2Br signaling reduces $\mathrm{PDE} 5$ gene expression in two mouse models of priapism (sickle cell disease mice and adenosine deaminasedeficient mice), and this is dependent on Hif- $1 \alpha$ (51).

\section{Management}

As the mechanisms underpinning recurrent ischemic priapism become clearer, additional opportunities for pharmacologic intervention and management will arise. The primary goal of pharmacologic management of recurrent ischemic priapism is to prevent additional episodes that increase the risk of progression to a major ischemic priapism event (47). The most common pharmacologic therapies for stuttering priapism involve hormone regulation, and more recently, PDE5 inhibitors (52,53).

Reducing circulating testosterone levels is believed to improve stuttering priapism by limiting the erectionpromoting effect of the androgen (12). This can be accomplished through GnRH agonists, 5-alpha reductase inhibitors (54), or ketoconazole. In a retrospective review of 17 patients with recurrent ischemic priapism, temporary hypogonadism was induced with 6 months of ketoconazole treatment. Ninety four percent of patients reported resolution of priapism while on treatment, and $29 \%$ reported no recurrence after discontinuation of treatment (55). On the other hand, hypogonadal men supplemented with topical testosterone do not experience higher rates of priapism (56), suggesting that modulating testosterone may be less beneficial than other molecular targets. While testosterone deficiency and priapism are common in sickle cell disease patients, a cross-sectional study of 50 men with sickle cell disease was not able to demonstrate an association between testosterone deficiency and priapism (57).

PDE5 inhibitor therapy represents a somewhat paradoxical approach to priapism management, as the drug is typically reserved for patients with erectile dysfunction. However, in a mouse model of priapism, low dose continuous PDE5 inhibitor therapy has been shown to normalize otherwise dysregulated PDE5 levels and decrease the frequency of priapism (38). Sustained NO releasing compounds have also been shown to normalize activated eNOS and other biochemical elements of erection signaling in mouse models of priapism (37). In a rat model of ischemic priapism, treatment with pentoxyfylline, a non-selective PDE inhibitor, reduced collagen density in the corpus cavernosum, possibly through mechanisms relating to inhibition of TGF- $\beta$ (58). Sildenafil may provide a vasculoprotective effect through increased expression of eNOS and inhibition of NADPH oxidase, the enzyme responsible for the production of the free radical superoxide (39). In the mouse model of subacute hemolysis described earlier, daily administration of sildenafil for 3 weeks has been shown to increase NO synthase and PDE5 activity, decrease reactive oxygen species, and lower intracavernous pressure during erection compared to untreated sub-acute hemolysis mice (46). The therapeutic effect of long-term low dose hydroxyurea to treat priapism in sickle cell patients may involve the NO signaling pathway (59).

In a retrospective evaluation of seven patients with recurrent priapism, daily sildenafil or tadalafil has been shown to reduce episodes of stuttering priapism (52). Most recently, a double-blinded placebo-controlled randomized controlled trial of 13 sickle cell disease patients with recurrent ischemic priapism was conducted with an 8 -week blinded phase followed by an 8 -week open-label phase during which all patients received treatment with daily sildenafil $50 \mathrm{mg}$. The primary outcome was a $50 \%$ reduction in the number of weekly priapism episodes. No difference was found between the sildenafil group and placebo group during the blinded phase of the study. During the open-label phase of the study after five patients were lost to follow-up, 5 of 8 patients by intention to treat analysis and 2 of 3 patients by per-protocol analysis experienced a $50 \%$ reduction in weekly priapism episodes (53). Though the results of this RCT were somewhat equivocal, current expert recommendation for patients with stuttering priapism is treatment with sildenafil $50 \mathrm{mg}$ daily, taken at a time completely unassociated with 
sexual activity (47). Higher doses may increase the risk of vaso-occlusive crisis in sickle cell disease patients $(47,60)$.

\section{Conclusions}

Further studies will continue to reveal the molecular mechanisms for priapism and suggest new therapeutic targets. Prevention of additional ischemic episodes remains the goal of therapy, and larger clinical trials will provide a more comprehensive evidence base from which stronger conclusions and recommendations can be drawn.

\section{Acknowledgements}

None.

\section{Footnote}

Conflicts of Interest: The authors have no conflicts of interest to declare.

\section{References}

1. Montague DK, Jarow J, Broderick GA, et al. American Urological Association guideline on the management of priapism. J Urol 2003;170:1318-24.

2. Lue TF, Garcia M. Should perioperative anticoagulation be an integral part of the priapism shunting procedure? Transl Androl Urol 2013;2:316-20.

3. Mwamukonda KB, Chi T, Shindel AW, et al. Androgen blockade for the treatment of high-flow priapism. J Sex Med 2010;7:2532-7.

4. Shigehara K, Namiki M. Clinical Management of Priapism: A Review. World J Mens Health 2016;34:1-8.

5. Roghmann F, Becker A, Sammon JD, et al. Incidence of priapism in emergency departments in the United States. J Urol 2013;190:1275-80.

6. Spycher MA, Hauri D. The ultrastructure of the erectile tissue in priapism. J Urol 1986;135:142-7.

7. Broderick GA, Kadioglu A, Bivalacqua TJ, et al. Priapism: pathogenesis, epidemiology, and management. J Sex Med 2010;7:476-500.

8. Carson CC, Mino RD. Priapism Associated with Trazodone Therapy. J Urol 1988;139:369-70.

9. Eiland LS, Bell EA, Erramouspe J. Priapism associated with the use of stimulant medications and atomoxetine for attention-deficit/hyperactivity disorder in children. Ann Pharmacother 2014;48:1350-5.
10. Todd NV. Priapism in acute spinal cord injury. Spinal Cord 2011;49:1033-5.

11. Burnett AL, Bivalacqua TJ. Glucose-6-phosphate dehydrogenase deficiency: an etiology for idiopathic priapism? J Sex Med 2008;5:237-40.

12. Salonia A, Eardley I, Giuliano F, et al. European Association of Urology guidelines on priapism. Eur Urol 2014;65:480-9.

13. Fowler JE, Koshy M, Strub M, et al. Priapism associated with the sickle cell hemoglobinopathies: prevalence, natural history and sequelae. J Urol 1991;145:65-8.

14. Anele UA, Burnett AL. Erectile Dysfunction after Sickle Cell Disease-Associated Recurrent Ischemic Priapism: Profile and Risk Factors. J Sex Med 2015;12:713-9.

15. Kovac JR, Mak SK, Garcia MM, et al. A pathophysiologybased approach to the management of early priapism. Asian J Androl 2013;15:20-6.

16. Martin C, Cocchio C. Effect of phenylephrine and terbutaline on ischemic priapism: a retrospective review. Am J Emerg Med 2016;34:222-4.

17. Segal RL, Readal N, Pierorazio PM, et al. Corporal Burnett "Snake" surgical maneuver for the treatment of ischemic priapism: long-term followup. J Urol 2013;189:1025-9.

18. Garcia MM, Shindel AW, Lue TF. T-shunt with or without tunnelling for prolonged ischaemic priapism. BJU Int 2008;102:1754-64.

19. Quackles R. Cure of a patient suffering from priapism by cavernospongiosa anastomosis. Acta Urol Belg 1964;32:5.

20. Barry JM. Priapism: treatment with corpus cavernosum to dorsal vein of penis shunts. J Urol 1976;116:754-6.

21. Brant WO, Garcia MM, Bella AJ, et al. T-shaped shunt and intracavernous tunneling for prolonged ischemic priapism. J Urol 2009;181:1699-705.

22. Burnett AL, Pierorazio PM. Corporal "snake" maneuver: corporoglanular shunt surgical modification for ischemic priapism. J Sex Med 2009;6:1171-6.

23. Zacharakis E, Garaffa G, Raheem AA, et al. Penile prosthesis insertion in patients with refractory ischaemic priapism: early vs delayed implantation. BJU Int 2014;114:576-81.

24. Zacharakis E, De Luca F, Raheem AA, et al. Early insertion of a malleable penile prosthesis in ischaemic priapism allows later upsizing of the cylinders. Scand J Urol 2015;1-4. [Epub ahead of print].

25. Tausch TJ, Zhao LC, Morey AF, et al. Malleable Penile Prosthesis Is a Cost-Effective Treatment for Refractory Ischemic Priapism. J Sex Med. 2015;12:824-6. 
26. Cahn D, Courter E, Diorio G, et al. Case Report: Conversion of a Low-Flow to High-Flow Priapism. Curr Urol 2015;8:101-3.

27. Brock G, Breza J, Lue TF, et al. High flow priapism: a spectrum of disease. J Urol 1993;150:968-71.

28. Wu AK, Lue TF. Commentary on high flow, nonischemic, priapism. Transl Androl Urol 2012;1:109-12.

29. Kim KR, Shin JH, Song HY, et al. Treatment of high-flow priapism with superselective transcatheter embolization in 27 patients: a multicenter study. J Vasc Interv Radiol 2007;18:1222-6.

30. Hakim LS, Kulaksizoglu H, Mulligan R, et al. Evolving concepts in the diagnosis and treatment of arterial high flow priapism. J Urol 1996;155:541-8.

31. Tan XZ, Liu Y, Guo YQ, et al. Post-traumatic Highflow Priapism: Multidetector Computed Tomography Demonstration. Urology 2015;86:e25-6.

32. Tokue H, Shibuya K, Ueno H, et al. Percutaneous Direct Puncture Embolization with N-butyl-cyanoacrylate for High-flow Priapism. Cardiovasc Intervent Radiol 2016;39:1343-6.

33. Adeyoju AB, Olujohungbe ABK, Morris J, et al. Priapism in sickle-cell disease; incidence, risk factors and complications - an international multicentre study. BJU Int 2002;90:898-902 .

34. Cita KC, Brureau L, Lemonne N, et al. Men with Sickle Cell Anemia and Priapism Exhibit Increased Hemolytic Rate, Decreased Red Blood Cell Deformability and Increased Red Blood Cell Aggregate Strength. PLoS One 2016;11:e0154866.

35. Champion HC, Bivalacqua TJ, Takimoto E, et al. Phosphodiesterase-5A dysregulation in penile erectile tissue is a mechanism of priapism. Proc Natl Acad Sci USA 2005;102:1661-6.

36. Burnett AL, Lowenstein CJ, Bredt DS, et al. Nitric oxide: a physiologic mediator of penile erection. Science 1992;257:401-3.

37. Lagoda G, Sezen SF, Hurt KJ, et al. Sustained nitric oxide (NO)-releasing compound reverses dysregulated NO signal transduction in priapism. FASEB J 2014;28:76-84.

38. Bivalacqua TJ, Musicki B, Hsu LL, et al. Sildenafil Citrate-Restored eNOS and PDE5 Regulation in Sickle Cell Mouse Penis Prevents Priapism Via Control of Oxidative/Nitrosative Stress. Koul H, editor. PLoS One 2013;8:e68028.

39. Musicki B, Bivalacqua TJ, Champion HC, et al. Sildenafil Promotes eNOS Activation and Inhibits NADPH Oxidase in the Transgenic Sickle Cell Mouse Penis. J Sex Med
2014;11:424-30.

40. Anele UA, Burnett AL. Nitrergic Mechanisms for Management of Recurrent Priapism. Sex Med Rev 2015;3:160-8.

41. Lue TF. Erectile dysfunction. N Engl J Med 2000;342:1802-13.

42. Rajfer J, Aronson WJ, Bush PA, et al. Nitric Oxide as a Mediator of Relaxation of the Corpus Cavernosum in Response to Nonadrenergic, Noncholinergic Neurotransmission. N Engl J Med 1992;326:90-4.

43. Corbin JD, Francis SH. Cyclic GMP Phosphodiesterase-5: Target of Sildenafil. J Biol Chem 1999;274:13729-32.

44. Corbin JD. Mechanisms of action of PDE5 inhibition in erectile dysfunction. Int J Impot Res 2004;16 Suppl 1:S4-7.

45. Bivalacqua TJ, Musicki B, Kutlu O, et al. New Insights into the Pathophysiology of Sickle Cell Disease Associated Priapism. J Sex Med 2012;9:79-87.

46. Sopko NA, Matsui H, Hannan JL, et al. Subacute Hemolysis in Sickle Cell Mice Causes Priapism Secondary to NO Imbalance and PDE5 Dysregulation. J Sex Med 2015;12:1878-85.

47. Anele UA, Le BV, Resar LM, et al. How I treat priapism. Blood 2015;125:3551-8.

48. Dai Y, Zhang Y, Phatarpekar P, et al. Adenosine signaling, priapism and novel therapies. J Sex Med 2009;6 Suppl 3:292-301.

49. Fu S, Davies KP. Opiorphin-dependent upregulation of CD73 (a key enzyme in the adenosine signaling pathway) in corporal smooth muscle cells exposed to hypoxic conditions and in corporal tissue in pre-priapic sickle cell mice. Int J Impot Res 2015;27:140-5.

50. Fu S, Tar MT, Melman A, et al. Opiorphin is a master regulator of the hypoxic response in corporal smooth muscle cells. FASEB J 2014;28:3633-44.

51. Ning C, Wen J, Zhang Y, et al. Excess adenosine A2B receptor signaling contributes to priapism through $\mathrm{HIF}$ 1 mediated reduction of PDE5 gene expression. FASEB J 2014;28:2725-35.

52. Burnett AL, Bivalacqua TJ, Champion HC, et al. Feasibility of the Use of Phosphodiesterase Type 5 Inhibitors in a Pharmacologic Prevention Program for Recurrent Priapism. J Sex Med 2006;3:1077-84.

53. Burnett AL, Anele UA, Trueheart IN, et al. Randomized controlled trial of sildenafil for preventing recurrent ischemic priapism in sickle cell disease. Am J Med 2014;127:664-8.

54. Rachid-Filho D, Cavalcanti AG, Favorito LA, et al. Treatment of Recurrent Priapism in Sickle Cell 
Anemia With Finasteride: A New Approach. Urology 2009;74:1054-7.

55. Hoeh MP, Levine LA. Prevention of recurrent ischemic priapism with ketoconazole: evolution of a treatment protocol and patient outcomes. J Sex Med 2014;11:197-204.

56. Burnett AL, Kan Dobrosky N, Miller MG. Testosterone Replacement with 1\% Testosterone Gel and Priapism: No Definite Risk Relationship. J Sex Med 2013;10:1151-61.

57. Morrison BF, Anele UA, Reid ME, et al. Is testosterone deficiency a possible risk factor for priapism associated with sickle-cell disease? Int Urol Nephrol 2015;47:47-52.

58. Erdemir F, Firat F, Markoc F, et al. The effect of

Cite this article as: Hudnall M, Reed-Maldonado AB, Lue TF. Advances in the understanding of priapism. Transl Androl Urol 2017;6(2):199-206. doi: 10.21037/tau.2017.01.18 pentoxifylline on penile cavernosal tissues in ischemic priapism-induced rat model. Int Urol Nephrol 2014;46:1961-7.

59. Anele UA, Kyle Mack A, Resar LM, et al. Hydroxyurea therapy for priapism prevention and erectile function recovery in sickle cell disease: a case report and review of the literature. Int Urol Nephrol 2014;46:1733-6.

60. Machado RF, Barst RJ, Yovetich NA, et al. Hospitalization for pain in patients with sickle cell disease treated with sildenafil for elevated TRV and low exercise capacity. Blood 2011;118:855-64. 